THE EFFECTIVENESS OF INDUSTRIAL AND TECHNOLOGICAL VOCATIONAL HIGH SCHOOL (ITVHS)

\author{
Sumarno \\ Universitas Negeri Medan \\ masno63@yahoo.co.id
}

\begin{abstract}
This research is aimed at revealing the effectiveness of Industrial and Technological Vocational High School (ITVHS) in terms of 1) the graduate participation on major industry and production unit, and 2) the indicator of future labor market (IFLM) for ITVHS graduate. The subject of this research was ITHVS graduate workforces of Bandar Lampung Municipality. Data were collected through documentation and were analyzed using the descriptive analyses and IFLM equation proposed by Grip and Heijke (1998). Findings suggested that 1) at the industrial production unit, the graduate of Mechanical Engineering Department participated effectively with participation rate of 0.66 to 0.76 , graduate of Civil Engineering Department participated effectively with the participation rate of 0.58 , and graduate of electrical engineering department did not participate effectively with the participation rate of 0.43 . The IFLM that showed the value of 4.66 indicated that the ITVHS was not effective.
\end{abstract}

Key words: participation rate, IFLM 


\title{
KEEFEKTIFAN PROGRAM SEKOLAH MENENGAH KEJURUAN TEKNOLOGI DAN INDUSTRI (SMKTI)
}

\begin{abstract}
Abstrak
Penelitian ini bertujuan untuk mengetahui keefektifan program pendidikan Sekolah Menengah Kejuruan Teknologi Industri (SMKTI), yang mencakup: (1) angka partisipasi lulusan Jurusan Mesin, Elektro, dan Bangunan pada industri utama dan unit produksi, dan (2) indikator pasar tenaga kerja lulusan pada waktu mendatang. Subjek penelitian ini adalah tenaga kerja lulusan SMKTI Kota Bandar Lampung. Data penelitian dikumpulkan melalui dokumentasi dan dianalisis secara deskriptif. Untuk mengetahui indikator prospek pasar tenaga kerja lulusan SMKTI digunakan persamaan Grip dan Heijke (1998). Hasil penelitian menunjukkan bahwa: (1) pada unit produksi, jurusan teknik mesin mempunyai angka partisipasi 0,66 sampai 0,76 (efektif), jurusan teknik bangunan mempunyai angka partisipasi 0,58 (efektif), dan jurusan teknik elektro mempunyai angka partisipasi 0,36 sampai 0,43 (tidak efektif). (2) Indikator pasar tenaga kerja yang akan datang bagi lulusan SMKTI $=4,66$. Indikator ini menunjukkan bahwa program pendidikan SMKTI tidak efektif.

Kata kunci: efektivitas program, angka partisipasi, indikator pasar tenaga kerja lulusan
\end{abstract}

\section{Pendahuluan}

Sistem Pendidikan Nasional, secara tidak langsung, memuat pernyataan dinyatakan bahwa pengembangan SDM dapat diselenggarakan melalui dua macam jalur atau sekolah; yaitu sekolah yang lulusannya diorientasikan untuk melanjutkan ke perguruan tinggi, yang disebut dengan Sekolah Menengah Atas (SMA) dan sekolah yang diorientasikan untuk mempersiapkan anak didik memasuki dunia kerja, yang dikenal dengan 
Sekolah Menengah Kejuruan (SMK). SMK yang mengorientasikan lulusan dalam bidang teknologi dan industri disebut SMKTI.

SMKTI Kota Bandar Lampung menghadapi problem kesepadanan kualitatif dan kuantitatif. Problem kesepadanan kuantitatif terjadi karena adanya ketidakseimbangan antara persediaan dan permintaan tenaga kerja. Permintaan dunia usaha/industri jauh sangat sedikit dibandingkan jumlah lulusan SMKTI. Problem kesepadanan kualitatif terjadi karena lapangan kerja mengalami perubahan begitu cepat, sehingga mengakibatkan kesejangan kompetensi yang dimiliki lulusan SMKTI dengan kompetensi yang dibutuhkan dunia kerja.

Evaluasi program digunakan untuk menyediakan informasi tentang program (Pasovac \& Carey, 1985). Informasi ini meliputi gambaran program, apakah program tersebut memadai untuk memenuhi kebutuhan yang telah diidentifikasi, apakah program yang telah dilakukan seperti yang diharapkan, dan apakah program tersebut sungguh-sungguh membantu peserta didik tentang apa yang dibutuhkan. Untuk mengetahui keadaan (keefektifan) program pendidikan SMKTI saat ini, diajukan rumusan masalah sebagai berikut:

a. Bagaimanakah keefektifan program pendidikan SMKTI dilihat dari angka partisipasi masing-masing jurusan (teknik mesin, elektro, dan bangunan) di industri utama?

b. Bagaimanakah keefektifan program pendidikan SMKTI dilihat dari angka partisipasi masing-masing jurusan (teknik mesin, elektro, dan bangunan) di unit produksi?

c. Bagaimanakah keefektifan program SMKTI dilihat indicator of future labour market (IFLM) lulusan SMKTI?

Hakikat Sekolah Menengah Kejuruan

Dewey menggambarkan pendidikan kejuruan sebagai proses sepanjang hidup yang membantu individu menemukan arah dan makna di dalam kehidupannya (Shumer, 2001). Berdasarkan pendapat Dewey dapat digarisbawahi bahwa pendidikan kejuruan telah ada dan sama tuanya dengan sejarah peradaban manusia. 
Pendidikan kejuruan bermula ketika orang tua mengajari anakanaknya keterampilan-keterampilan (skills) yang dibutuhkan untuk melangsungkan hidup, seperti berburu pada masyarakat primitif. Pada masa itu anak-anak belajar keterampilan dari orang tuanya melalui melihat dan mencontoh proses yang dilakukan orang tuanya sehingga anaknya akan melakukan keterampilan yang sama dengan yang dilakukan orang tuanya (Gallinelli, 1979).

Sejalan dengan sejarah perkembangan manusia, pendidikan kejuruan menunjukkan perkembangannya. Salah satu indikasi perkembangan tersebut adalah adanya berbagai bidang keahlian atau program keahlian yang ditawarkan oleh institusi pendidikan kejuruan. Menurut Miller (1986) pendidikan kejuruan mempunyai tiga elemen pokok, yaitu: nature of reality, truth, and value. Pendapat ini menunjukkan bahwa pelaksanaan pendidikan kejuruan tidak dapat dipisahkan dari kegiatan praktik. Integrasi belajar akademik dengan keterampilan dan pengetahuan praktik merupakan salah satu penekanan utama dalam pendidikan kejuruan selama beberapa dasawarsa.

Belajar dalam praksis pendidikan kejuruan di sekolah tidak dapat dipisahkan dari situasi-situasi kehidupan dan tempat kerja adalah seting penting yang membantu individu belajar tentang karir, keterampilan kerja, pengembangan personal, dan aplikasi keterampilan hidup (Shumer, 2001). Hal ini didukung oleh Hermanussen, dkk. (2000) yang menyatakan bahwa an important component of vocational education program is work experience.

Pernyataan tentang keterkaitan antara sekolah kejuruan dan industri juga diutarakan oleh Charles Prosser (Camp \& Hillison, 1984). Menurut beliau ada 16 butir filosofi pendidikan kejuruan agar pendidikan kejuruan benar-benar mempunyai tingkat efiensi dan relevanasi yang tinggi. Dari keenam belas butir tersebut ada delapan butir yang menunjukkan bahwa pelaksanaan pendidikan kejuruan harus memiliki keterkaitan dan kesepadanan (link and match) dengan dunia industri atau pasar tenaga kerja. Keterkaitan dan kesepadanan ini meliputi: kondisi lingkungan yang harus disediakan oleh SMK, tugas dan program yang disediakan, fasilitas atau peralatan yang harus digunakan, praktik yang dilakukan, dan perkembangan keterampilan yang perlu dikembangkan. Kedelapan butir tersebut yaitu: 
1. Pendidikan kejuruan akan efisien apabila disediakan lingkungan yang sesuai dengan kondisi nyata di mana lulusan akan bekerja.

2. Pendidikan kejuruan akan efektif bilamana latihan dan tugas yang diberikan secara langsung dan spesifik (dalam arti mengerjakan benda kerja yang sesungguhnya, bukan sekedar tiruan).

3. Latihan kejuruan akan efektif apabila diberikan tugas atau program sesuai dengan apa yang akan dikerjakan kelak. Dengan demikian fasilitas atau peralatan beserta proses kerja dan operasionalnya dibuat sama dengan kondisi nyata nantinya.

4. Pendidikan kejuruan akan efektif bilamana dalam latihan kerja atau dalam pengerjaan tugas sudah dibiasakan pada kondisi nyata nantinya.

5. Pendidikan kejuruan akan efektif apabila memperhatikan kondisi pasar kerja.

6. Pendidikan kejuruan akan efektif bilamana mampu memberikan bekal kemampuan minimal yang dibutuhkan dunia kerja (sebagai standar minimal profesi), sehingga mudah adaptif dan pengembangannya.

7. Sumber data yang dipergunakan untuk menentukan program pendidikan kejuruan didasarkan atas pengalaman nyata pekerjaan di lapangan.

8. Pendidikan kejuruan akan efisien apabila sebagai lembaga pendidikan yang menyiapakan sumber daya manusia untuk memenuhi kebutuhan dunia kerja tertentu dan dalam waktu tertentu.

Kenyataan di lapangan menunjukkan bahwa perkembangan teknologi (dalam arti alat, proses, maupun ilmu pengetahuan) yang ada didunia kerja jauh lebih cepat jika dibandingkan dengan teknologi yang ada di sekolah, sehingga berakibat pada semakin jauhnya kesenjangan keterkaitan dan kesepadanan antara dunia industri dan sekolah. Untuk memperkecil kesenjangan antara permintaan industri dan lulusan SMKTI dalam aspek kualitatif (kompetensi) maupun kuantitatif (persentase partisipasi lulusan, permintaan jumlah lulusan), maka pihak sekolah harus selalu dapat memahami dan menyikapi kesenjangan tersebut, yaitu dengan menjalin kerjasama yang baik, terprogram, dan terarah dengan dunia industri. 
Evaluasi Program Pendidikan SMKTI

Program pendidikan merupakan bagian utama dari industri layanan manusia (Pasovac \& Carey, 1985). SMKTI sebagai sistem tersusun atas komponen konteks, input, proses, output, dan outcome (KIPOO) (Slamet, 2005). Komponen KIPOO ini menunjukkan bahwa dalam pembangunan pendidikan SMKTI jangan dipandang semata-mata sebagai suatu gejala persedian (supply phenomena) dengan persoalan-persoalan yang hanya terpusat pada bagaimana menghasilkan lulusan sebanyak-banyaknya dan bagaimana meningkatkan mutu pendidikan, akan tetapi pendidikan harus dipandang sebagai fenomena permintaan (demand phenomena) dengan persoalan utama untuk apa lulusan dihasilkan atau untuk apa mutu ditingkatkan (Boediono, 1997).

Evaluasi program diperlukan untuk menentukan apakah program dibutuhkan dan mungkin untuk dilaksanakan, apakah program tersebut memadai untuk memenuhi kebutuhan yang telah diidentifikasi, apakah program yang telah dilakukan seperti yang diharapkan, dan apakah program tersebut sungguh-sungguh membantu pengguna tentang apa yang dibutuhkan; dengan kata lain evaluasi program berusaha untuk menyediakan informasi tentang program (Pasovac \& Carey, 1985). Menurut McMillan \& Schumacher (2001) evaluasi dapat membantu membuat perencanaan, menginstalasi program, membantu membuat keputusan tentang modifikasi program, dapat membantu membuat keputusan tentang keberlangsungan dan perluasan program, dan mendapatkan bukti adanya dukungan atau hambatan terhadap program.

Pendekatan yang dapat digunakan untuk memperoleh, menggambarkan, dan menyediakan informasi yang berkenaan dengan permintaan masyarakat (lulusan SMP/MTs) terhadap SMKTI adalah pendekatan social demand for education dan yang berkenaan dengan permintaan industri/dunia usaha terhadap lulusan SMKTI adalah pendekatan kebutuhan tenaga kerja (manpower requirement approach). Menurut Hough (1993) pendekatan yang menggabungkan dua pendekatan yang ada disebut dengan model sintetik (synthetic model). 


\section{Keefektifan Program Pendidikan}

Indikator keefektifan program pendidikan dapat dikelompokkan menjadi dua kelompok besar yaitu kelompok stage yang pertama (input dan proses) dan kelompok stage yang kedua (output dan outcome). Indikator keefektifan program stage pertama komponen input mencakup sub komponen: karakteristik guru, fasilitas, perlengkapan, material pendidikan, dan kapasitas administratif. Indikator keefektifan program stage pertama komponen proses mencakup sub komponen: perilaku administratif, alokasi waktu guru, dan alokasi waktu peserta didik. Indikator keefektifan program stage kedua komponen output mencakup sub komponen: attainment effects, efek perilaku dan sikap, dan efek kewajaran kesetaraan (equity effects of equality). Indikator keefektifan program stage kedua komponen outcome mencakup sub komponen: pengakuan untuk mengikuti pendidikan dan latihan lebih lanjut, prestasi pada pendidikan dan latihan lebih lanjut, penempatan kerja (employment), penghasilan (earning), sikap dan perilaku, dan eksternalitas (Windham, 1990).

Evaluasi keefektifan program pada penelitian dibatasi pada stage kedua sub komponen outcome, yaitu pemekerjaan (employment). Menurut Windham (1990) term employment mencakup range aktivitas mulai dari pekerjaan rumah tangga, bekerja mandiri, wirausaha informal dan formal, dan bekerja di sektor industri modern. Pada penelitian ini range aktivitas term employment dibatasi pada sektor industri modern (partisipasi lulusan di industri modern, dan indikator pasar tenaga kerja yang akan datang), sebagaimana yang dinyatakan oleh Windham (1990) diskusi keefektifan program pendidikan sering dibatasi pada sektor industri modern, walaupun efek pendidikan dapat dinyatakan dalam bentuk employment yang lain.

Data dan Teknik Analisis Data

Teknik pengambilan sampel dilakukan secara purposive sampling, yaitu dilakukan di 21 industri/perusahaan yang ada di Kota Bandar Lampung yang dalam proses produksinya atau proses pembuatan nilai tambahnya cenderung mempekerjakan tenaga kerja lulusan SMKTI (major industry). Ke21 industri tersebut terdiri atas 1 industri konstruksi baja, 4 industri kerja 
logam (bengkel), 6 bengkel mobil, 2 bengkel motor, 2 industri elektronik, 3 industri bangunan dan teknik sipil, 2 kontraktor listrik, dan 1 industri pengolahan kayu.

Pendekatan yang digunakan untuk memperoleh, menggambarkan, dan menyediakan informasi yang berkenaan dengan permintaan masyarakat terhadap lulusan SMKTI adalah pendekatan kebutuhan tenaga kerja (manpower requirement approach). Untuk mengetahui permintaan baru terhadap tenaga kerja lulusan SMKTI dilakukan dengan mencermati perkembangan lowongan kerja. Departemen yang mengelola informasi ini adalah departemen tenaga kerja. Pada tingkat lokal (kota/kabupaten) informasi ini ditangani oleh Dinas Tenaga Kerja. Menurut Fung (2001) public employment service yang disediakan oleh lembaga (Departemen/Dinas Tenaga Kerja) dan iklan kesempatan kerja (job advertisements) menggambarkan efek perubahan teknologi.

Permintaan industri terhadap tenaga kerja lulusan SMKTI dapat digambarkan dengan persamaan matematis seperti yang pernah digunakan oleh Parnes (Willems, 1996). Langkah-langkah yang ditempuh adalah pertama menentukan jumlah tenaga kerja total dari industri-industri yang ada kecenderungan menggunakan tenaga kerja lulusan SMKTI (major industry). Kedua, berdasarkan angka partisipasi (partisipasi) tenaga produksi yang diperoleh pada studi pendahuluan, dihitung tenaga produksi dari masing-masing industri. Partisipasi tenaga produksi adalah hasil bagi jumlah tenaga produksi dengan jumlah tenaga kerja total. Ketiga, berdasarkan pada partisipasi tenaga lulusan SMKTI di masing-masing unit produksi yang diperoleh pada studi pendahuluan, dihitung jumlah tenaga kerja lulusan SMKTI. Partisipasi tenaga kerja lulusan SMKTI di masing-masing unit produksi adalah hasil bagi jumlah tenaga kerja lulusan SMKTI dibagi dengan jumlah tenaga kerja yang ada di unit produksi.

Penghitungan jumlah tenaga kerja total dari industri utama (major industry) dilakukan dengan menjumlah jumlah tenaga kerja pada industri sedang dan besar (hasil survei 2002, 2003, 2004) dan jumlah tenaga kerja dari industri kecil dan rumah tangga yang diperoleh dari Dinas Tenaga Kerja pada tahun yang sama. Secara matematis dituliskan sebagai berikut: 


$$
L_{t}^{d}=\sum L_{i, t}
$$

dengan:

$$
\begin{array}{ll}
d_{t} & =\text { jumlah tenaga kerja total pada saat } \mathrm{t} \\
\Sigma_{L i, t} & =\text { jumlah tenaga total industri i pada saat } \mathrm{t}
\end{array}
$$

Persamaan jumlah tenaga di unit produksi menurut Willems (1996: 5).

$$
\stackrel{d}{L j, t}=\sum_{t} n i, j, t \cdot L_{i, t}^{d}
$$

dengan:

$$
\begin{aligned}
\frac{d j, t}{L_{j, t}}= & \text { jumlah tenaga kerja produksi pada saat } \mathrm{t} \\
n i, j, t= & \text { angka partisipasi (partisipasi) tenaga produksi pada } \\
& \text { industri i, pada saat } \mathrm{t} \\
d & =\text { jumlah tenaga kerja total pada saat } \mathrm{t}
\end{aligned}
$$

Persamaan jumlah tenaga kerja lulusan SMKTI berdasarkan persamaan (2) dinyatakan dengan:

$$
\stackrel{d}{L k, t}=\sum_{n j, k, t} \stackrel{d}{L_{j, t}}
$$

dengan:

$$
\begin{aligned}
\underset{L_{k, t}}{d}= & \text { jumlah tenaga kerja lulusan SMKTI pada saat } \mathrm{t} \\
n_{j, k, t}= & \text { partisipasi tenaga kerja lulusan SMKTI pada bagian } \\
& \text { produksi pada saat } \mathrm{t} \\
{ }_{{ }_{j, t}} & =\text { jumlah tenaga kerja produksi pada saat } \mathrm{t}
\end{aligned}
$$

Besarnya partisipasi lulusan SMKTI pada masing-masing unit produksi merupakan indikasi keefektifan program. Bila angka partisipasi pada unit produksi lebih dari 0,5; maka dapat dinyatakan bahwa program pendidikan SMKTI dapat dinyatakan efektif. 
Prospek pasar tenaga kerja bagi pendatang baru (lulusan SMKTI) dapat digambarkan menggunakan persamaan indikator prospek pasar tenaga kerja yang akan datang (Indicator of Future Labor Market Prospects = IFLM) seperti dinyatakan oleh Grip dan Heijke (1998: 41).

$$
\begin{aligned}
I_{e}= & \frac{E_{e 03}+I N S_{e 03-05}+U_{e 03}}{E_{e 03}+\max \left(0 ; E D_{e 03-05}\right)+R D_{e 03-05}+S D_{e 03-05}} \\
E_{e 03}= & \text { jumlah pekerja dari pendidikan SMKTI pada tahun } 2003 \\
I N S_{e 03-05}= & \text { arus lulusan SMKTI selama periode 2003-2005 } \\
U_{e 03}= & \text { jumlah lulusan SMKTI yang menganggur kurang dari satu } \\
& \text { tahun pada tahun 2003 } \\
E D_{e 03-05}= & \text { permintaan ekspansi untuk lulusan SMKTI selama } \\
& \text { periode 2003-2005 } \\
R D_{e 03-05}= & \begin{array}{l}
\text { permintaan pengganti untuk lulusan SMKTI selama } \\
\text { periode 2003-2005 (forecast replacement demand) }
\end{array} \\
S D e_{03-05}= & \begin{array}{l}
\text { permintaan penggantian ramalan untuk lulusan SMKTI } \\
\text { karena supply-demand yang tidak sepadan dari tipe } \\
\text { pendidikan yang lain (forecast substitution demand) }
\end{array}
\end{aligned}
$$

Indikator yang digunakan untuk mengidentifikasikan prospek pasar tenaga kerja yang akan datang bagi lulusan SMKTI, digunakan kriteria:

- jika persediaan tenaga kerja lebih sedikit dari permintaan, dan IFLM < 0,85; pasar tenaga kerja yang akan datang bagi lulusan SMKTI dinyatakan sangat baik.

- $0,85 \leq$ IFLM < 1,00; pasar tenaga kerja dinyatakan baik (efektif).

- 1,00 $\leq$ IFLM $\leq 1,15$; pasar tenaga kerja dinyatakan cukup (cukup efektif).

- IFLM > 1,15; pasar tenaga kerja dinyatakan buruk (tidak efektif). 


\section{Hasil Penelitian dan Pembahasan}

Partisipasi setiap bidang keahlian pada sektor industri, dan partisipasi pada devisi produksi dari tahun 2002 hingga 2004 (Tabel 1 dan Tabel 2) menunjukkan bahwa partisipasi bidang keahlian Teknik Mesin pada industri otomotif dalam kondisi konstan. Sifat konstan ini ditunjukkan dengan adanya 100 orang yang bekerja di industri otomotif, diperkirakan ada 29 orang yang mempunyai latar belakang bidang keahlian Teknik Mesin. Apabila tahun 2002 dijadikan acuan patokan, maka dapat dinyatakan bahwa minat industri logam dan kerja mesin untuk merekrut lulusan SMKTI bidang keahlian Teknik Mesin mengalami peningkatan. Pada tahun 2002 diperkirakan ada 54 orang yang mempunyai latar belakang bidang keahlian Teknik Mesin dalam setiap 100 orang tenaga kerja pada industri logam dan kerja mesin meningkat menjadi 56 orang pada tahun 2003, dan menjadi 55 orang pada tahun 2004. Pada industri yang lainnya partisipasi bidang keahlian Teknik Mesin tidak mengalami perubahan.

Tabel 1. Perkembangan Partisipasi Bidang Keahlian Teknik Mesin pada Sektor Industri

\begin{tabular}{|l|c|c|c|}
\hline \multirow{2}{*}{\multicolumn{1}{|c|}{ Sektor Industri }} & \multicolumn{3}{|c|}{ Tahun } \\
\cline { 2 - 4 } & 2002 & 2003 & 2004 \\
\hline Industri Bangunan dan Teknik Sipil & 0,00 & 0,00 & 0,00 \\
\hline Industri Otomotif & 0,29 & 0,29 & 0,29 \\
\hline Kontraktor Listrik & 0,05 & 0,05 & 0,04 \\
\hline Perusahaan Elektronika & 0,00 & 0,00 & 0,00 \\
\hline Industri Logam dan Kerja Mesin & 0,54 & 0,56 & 0,55 \\
\hline Industri Pertambangan & 0,21 & 0,21 & 0,21 \\
\hline Industri Pengolahan Kayu & 0,05 & 0,05 & 0,05 \\
\hline
\end{tabular}


Tabel 2. Perkembangan Partisipasi Bidang Keahlian Teknik Mesin pada Devisi Produksi

\begin{tabular}{|l|c|c|c|}
\hline \multirow{2}{*}{\multicolumn{1}{|c|}{ Devisi Produksi }} & \multicolumn{3}{c|}{ Tahun } \\
\cline { 2 - 4 } & 2002 & 2003 & 2004 \\
\hline Industri Bangunan dan Teknik Sipil & 0,00 & 0,00 & 0,00 \\
\hline Industri Otomotif & 0,75 & 0,76 & 0,76 \\
\hline Kontraktor Listrik & 0,07 & 0,07 & 0,06 \\
\hline Perusahaan Elektronika & 0,00 & 0,00 & 0,00 \\
\hline Industri Logam dan Kerja Mesin & 0,66 & 0,66 & 0,67 \\
\hline Industri Pertambangan & 0,46 & 0,46 & 0,46 \\
\hline Industri Pengolahan Kayu & 0,05 & 0,05 & 0,05 \\
\hline
\end{tabular}

Paparan Tabel 2 menunjukkan bahwa dari tahun 2002 hingga 2004 partisipasi bidang keahlian Teknik Mesin pada devisi produksi industri otomotif menunjukkan peningkatan. Pada tahun 2002 diperkirakan ada 75 orang lulusan SMKTI dengan keahlian Teknik Mesin dalam setiap 100 orang yang bekerja pada devisi produksi; menjadi 76 orang pada tahun 2003 dan tahun 2004. Pada devisi produksi industri logam dan kerja mesin menunjukkan peningkatan pada tahun 2004, pada tahun 2002 dan 2003 ada 66 orang lulusan SMKTI dengan keahlian Teknik Mesin pada setiap 100 yang bekerja pada devisi produksi meningkat menjadi 67 orang pada tahun 2004. Pada perusahaan kontraktor listrik, partisipasi bidang keahlian Teknik Mesin mengalami penurunan. Pada tahun 2002 dan 2003, diperkirakan ada 7 orang tenaga kerja lulusan SMKTI bidang keahlian Teknik Mesin dalam setiap 100 pekerja yang bekerja pada devisi produksi kontraktor listrik, pada tahun 2004 tinggal 6 orang. Pada industri lainnya partisipasi bidang keahlian Teknik Mesin tidak mengalami perubahan. Pada devisi produksi industri pertambangan partisipasi bidang keahlian Teknik Mesin cukup besar, yaitu lebih dari 40 orang mempunyai latar belakang keahlian Teknik Mesin dalam setiap 100 orang yang bekerja yang bekerja di devisi produksi. 
Tabel 3. Perkembangan Partisipasi Bidang Keahlian Teknik Elektro pada Sektor Industri

\begin{tabular}{|l|c|c|c|}
\hline \multirow{2}{*}{\multicolumn{1}{|c|}{ Sektor Industri }} & \multicolumn{3}{|c|}{ Tahun } \\
\cline { 2 - 4 } & 2002 & 2003 & 2004 \\
\hline Industri Bangunan dan Teknik Sipil & 0,05 & 0,05 & 0,05 \\
\hline Industri Otomotif & 0,00 & 0,00 & 0,00 \\
\hline Kontraktor Listrik & 0,26 & 0,26 & 0,23 \\
\hline Perusahaan Elektronika & 0,12 & 0,12 & 0,11 \\
\hline Industri Logam dan Kerja Mesin & 0,09 & 0,09 & 0,09 \\
\hline Industri Pertambangan & 0,06 & 0,06 & 0,06 \\
\hline Industri Pengolahan Kayu & 0,03 & 0,03 & 0,03 \\
\hline
\end{tabular}

Paparan Tabel 3 di atas menunjukkan bahwa pada tahun 2004, partisipasi bidang keahlian Teknik Elektro pada perusahaan kontraktor listrik mengalami penurunan. Pada tahun 2002 dan 2003 diperkirakan ada 26 orang yang mempunyai latar belakang bidang keahlian Teknik Elektro dalam setiap 100 orang tenaga kerja pada perusahaan kontraktor listrik, pada tahun 2004 berkurang menjadi 23 orang. Pada industri elektronika, partisipasi bidang keahlian Teknik Elektro juga mengalami penurunan. Pada tahun 2002 dan 2003 diperkirakan ada 12 orang lulusan SMKTI bidang keahlian Teknik Elektro dalam setiap 100 orang yang bekerja pada industri elektronika berkurang menjadi 11 orang pada tahun 2004. Sedangkan pada industri yang lainnya partisipasi bidang keahlian Teknik Elektro tidak berubah.

Tabel 4. Perkembangan Partisipasi Bidang Keahlian Teknik Elektro pada Devisi Produksi

\begin{tabular}{|l|c|c|c|}
\hline \multirow{2}{*}{ Devisi Produksi } & \multicolumn{3}{|c|}{ Tahun } \\
\cline { 2 - 4 } & 2002 & 2003 & 2004 \\
\hline Industri Bangunan dan Teknik Sipil & 0,05 & 0,05 & 0,05 \\
\hline Industri Otomotif & 0,00 & 0,00 & 0,00 \\
\hline Kontraktor Listrik & 0,36 & 0,36 & 0,31 \\
\hline Perusahaan Elektronika & 0,43 & 0,43 & 0,42 \\
\hline Industri Logam dan Kerja Mesin & 0,11 & 0,11 & 0,11 \\
\hline Industri Pertambangan & 0,13 & 0,13 & 0,13 \\
\hline Industri Pengolahan Kayu & 0,03 & 0,03 & 0,03 \\
\hline
\end{tabular}


Paparan Tabel 4 menunjukkan bahwa pada tahun 2004 partisipasi bidang keahlian Teknik Elektro pada devisi produksi perusahaan kontraktor listrik mengalami penurunan. Pada tahun 2002 dan 2003 diperkirakan ada 36 orang lulusan SMKTI dengan keahlian Teknik Elektro dalam setiap 100 orang yang bekerja pada devisi produksi; berkurang menjadi 31 orang pada tahun 2003 dan tahun 2004. Pada perusahaan elektronika partisipasi bidang keahlian Teknik Elektro juga mengalami penurunan. Pada tahun 2002 dan 2003 diperkirakan ada 43 orang lulusan SMKTI dengan keahlian Teknik Elektro dalam setiap 100 orang yang bekerja pada devisi produksi; berkurang menjadi 42 orang pada tahun 2003 dan tahun 2004, sedangkan pada industri yang lainnya tidak mengalami perubahan.

Tabel 5. Perkembangan Partisipasi Bidang Keahlian Teknik Bangunan pada Sektor Industri

\begin{tabular}{|l|c|c|c|}
\hline \multirow{2}{*}{\multicolumn{1}{|c|}{ Sektor Industri }} & \multicolumn{3}{|c|}{ Tahun } \\
\cline { 2 - 4 } & 2002 & 2003 & 2004 \\
\hline Industri Bangunan dan Teknik Sipil & 0,50 & 0,50 & 0,48 \\
\hline Industri Otomotif & 0,00 & 0,00 & 0,00 \\
\hline Kontraktor Listrik & 0,00 & 0,00 & 0,02 \\
\hline Perusahaan Elektronika & 0,00 & 0,00 & 0,00 \\
\hline Industri Logam dan Kerja Mesin & 0,03 & 0,03 & 0,03 \\
\hline Industri Pertambangan & 0,03 & 0,03 & 0,03 \\
\hline Industri Pengolahan Kayu & 0,007 & 0,007 & 0,01 \\
\hline
\end{tabular}

Paparan Tabel 5 menunjukkan bahwa pada tahun 2004 partisipasi bidang keahlian Teknik Bangunan pada industri bangunan dan teknik sipil mengalami penurunan dibandingkan dua tahun sebelumnya. Pada tahun 2002 dan 2003, diperkirakan ada 50 orang lulusan SMKTI bidang keahlian Teknik Bangunan dalam setiap 100 orang tenaga kerja yang bekerja pada industri bangunan dan teknik sipil; pada tahun 2004 berkurang menjadi 48 orang. Partisipasi bidang keahlian Teknik Bangunan pada industri pengolahan kayu mengalami peningkatan. Pada tahun 2002 dan 2003 diperkirakan tidak ada lulusan bidang keahlian Teknik Bangunan yang 
bekerja pada industri pengolahan kayu, pada tahun 2004 diperkirakan ada satu tenaga kerja lulusan SMKTI dalam setiap 100 orang yang bekerja pada industri pengolahan kayu tersebut. Pada tahun 2004, diperkirakan ada 4 orang lulusan bidang keahlian Teknik Bangunan dalam setiap 100 yang bekerja pada industri kontraktor listrik, yang pada tahun 2002 dan 2003 tidak ada. Pada industri yang lainnya partisipasi bidang keahlian Teknik Bangunan tidak mengalami perubahan.

Paparan Tabel 6 menunjukkan bahwa dari tahun 2002 hingga tahun 2004, partisipasi bidang keahlian Teknik Bangunan pada devisi produksi di sektor utama sebagian besar tidak mengalami perubahan. Partisipasi terbesar terjadi pada industri bangunan dan teknik sipil yaitu diperkirakan ada 58 orang lulusan SMKTI bidang keahlian Teknik Bangunan dalam setiap 100 orang yang bekerja pada devisi produksi industri tersebut. Partisipasi bidang keahlian Teknik Bangunan pada devisi produksi industri pertambangan diperkirakan ada 6 orang dalam setiap 100 orang yang bekerja, dalam industri logam dan kerja mesin diperkirakan ada 4 orang; pada industri pengolahan kayu diperikirakan ada 1 orang. Pada tahun 2004, partisipasi bidang keahlian Teknik Bangunan yang bekerja pada devisi produksi perusahaan kontraktor listrik, diperkirakan ada 6 orang dalam setiap 100 orang, sedangkan pada dua tahun sebelumnya tidak ada.

Tabel 6. Perkembangan Partisipasi Bidang Keahlian Teknik Bangunan pada Devisi Produksi

\begin{tabular}{|l|c|c|c|}
\hline \multirow{2}{*}{\multicolumn{1}{|c|}{ Devisi Produksi }} & \multicolumn{3}{c|}{ Tahun } \\
\cline { 2 - 4 } & 2002 & 2003 & 2004 \\
\hline Industri Bangunan dan Teknik Sipil & 0,58 & 0,58 & 0,58 \\
\hline Industri Otomotif & 0,00 & 0,00 & 0,00 \\
\hline Kontraktor Listrik & 0,00 & 0,00 & 0,02 \\
\hline Perusahaan Elektronika & 0,00 & 0,00 & 0,00 \\
\hline Industri Logam dan Kerja Mesin & 0,04 & 0,04 & 0,03 \\
\hline Industri Pertambangan & 0,06 & 0,06 & 0,06 \\
\hline Industri Pengolahan Kayu & 0,01 & 0,01 & 0,01 \\
\hline
\end{tabular}


Indikator situasi pasar kerja yang akan datang bagi lulusan SMKTI dapat diketahui setelah memperoleh besaran-besaran yang akan dimasukkan ke dalam persamaan IFLM (an indicator of the future labour market situation). Besaran-besaran tersebut yaitu: jumlah pekerja dengan latar belakang lulusan SMKTI untuk tahun $2003\left(E_{e 03}\right)$, arus lulusan SMKTI

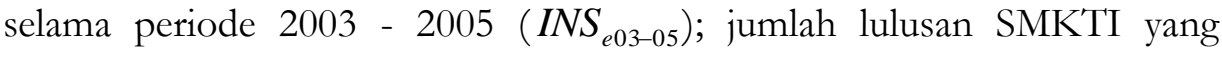
menganggur kurang dari satu tahun pada tahun 2003; permintaan ekspansi lulusan SMKTI selama periode 2003 - 2005 ( $\left.E D_{e 03-05}\right)$; permintaan pengganti ramalan lulusan SMKTI selama periode 2003-2005 $\left(R D_{e 03-05}\right)$; dan permintaan subsitusi $\left(S D_{e 03-05}\right)$. Besaran-besaran ini disajikan pada Tabel 7.

Tabel 7. Besaran-besaran untuk Analisis IFLM

\begin{tabular}{|c|c|}
\hline Besaran & Jumlah \\
\hline$E_{e 03}$ & 1922 \\
\hline$I N S_{e 03-05}$ & 5890 \\
\hline$U_{e 03}$ & 2214 \\
\hline$E D_{e 03-05}$ & 227 \\
\hline$R D_{e 03-05}$ & 0 \\
\hline$S D_{e 03-05}$ & 0 \\
\hline
\end{tabular}

Penghitungan $I F L M_{e}$ dengan memasukkan besaran-besaran di atas ke dalam persamaan IFLM diperoleh $\operatorname{IFLM}_{e}=4,66$. Karena $I F L M_{e}>$ 1,15 , maka dapat dinyatakan bahwa prospek pasar tenaga kerja yang akan datang bagi lulusan SMKTI buruk, berdasarkan indikator ini dapat dinyatakan bahwa program pendidikan SMKTI dilihat dari IFLM tidak efektif.

Temuan penelitian yang menunjukkan bahwa: (1) partisipasi bidang keahlian teknik bangungan efektif (angka partisipasi $>0,50$, pada industri 
bangunan), teknik elektro tidak efektif (angka partisipasi $<0,5$; baik di kontraktor listrik maupun perusahaan elektronika); dan bidang teknik mesin efektif (angka partisipasi $>0,5$, baik pada industri otomotif maupun industri logam dan mesin) merupakan informasi yang sangat berarti bagi perencanaan dan pengembangan SMKTI yang ada di Kota Bandar Lampung.

Gambaran di atas juga menunjukkan bahwa pengembangan program pendidikan SMKTI tidak dapat dipisahkan dari fenomena permintaan pasar (market demand). Seperti yang dinyatakan oleh Charles Prosser bahwa pendidikan kejuruan akan efektif apabila memperhatikan kondisi pasar kerja (Camp \& Hillison, 1984).

Kerjasama SMK dengan industri/perusahaan akan dapat dilaksanakan jika ada perusahaan/industri yang bersedia dan mampu menjadi pasangan dalam pelaksanaan pendidikan Sistem Ganda. Untuk itu para pengelola pendidikan SMK harus mampu mengambil inisiatif guna melakukan pendekatan dengan industri/perusahaan agar dapat melakukan program pendidikan kejuruan dengan Sistem Ganda tersebut (Djojonegoro, 1994). Pernyataan ini memunculkan anggapan bahwa industri mempunyai peran dan tanggungjawab pasif terhadap perkembangan pendidikan SMK, sedangkan yang harus aktif melakukan pendekatan dengan industri adalah SMK. Dengan kata lain masyarakat industri cenderung mengganggap bahwa pendidikan hanya merupakan tanggung jawab Depdiknas (pemerintah). Dengan anggapan seperti ini, maka masyarakat industri kurang merasa perduli dan tidak merasa terikat untuk turut serta memikirkan dan melaksanakan pendidikan kejuruan (Pakpahan, 2002).

Sejak diberlakukannya kurikulum SMK 1999, program pendidikan di SMK berorientasi pada pasar (demand driven atau market driven). Dengan paradigma demand driven, SMK menyelenggarakan pendidikan berdasarkan keperluan dunia usaha dan industri. Dengan demikian, dituntut adanya ikatan kerja yang erat dan sinergi antara sekolah dan industri. Dalam konsep ini dinyatakan bahwa tanggung jawab pendidikan kejuruan dipikul bersama oleh sektor pendidikan dan industri. Menurut Pakpahan (2002) dengan orientasi ini mengharapkan justru pihak dunia usaha atau dunia 
kerja yang seharusnya lebih berperan dalam menentukan, mendorong, dan menggerakkan pendidikan kejuruan, karena mereka adalah pihak yang lebih berkepentingan dari sudut tenaga kerja. Akhirnya dengan adanya ikatan kerja yang erat dan sinergi dapat diharapkan akan meningkatkan angka partisipasi (partisipasi) lulusan SMKTI di industri, dan akibat yang lebih jauh adalah terdorongnya orang tua/siswa lulusan SMP untuk memilih SMKTI sebagai pendidikan lanjutannya, karena mereka tahu tingkat kemudahannya dalam mendapatkan pekerjaan dibandingkan dengan lulusan SMA.

Besaran indikator situasi pasar tenaga kerja yang akan datang (indicator of future lobour market $=$ IFLM) bagi lulusan SMKTI adalah 4,66; yang berarti prospek pasar tenaga kerja yang akan datang bagi lulusan SMKTI termasuk dalam kategori buruk (program tidak efektif). Besaran ini ditentukan oleh jumlah pekerja dengan latar belakang pendidikan SMKTI yang telah diserap industri, arus (jumlah) tamatan SMKTI, jumlah lulusan SMKTI yang menganggur, permintaan industri terhadap lulusan SMKTI karena ekspansi, permintaan industri terhadap lulusan SMKTI karena ada pekerja yang pensiun atau mengundurkan diri, dan masuknya lulusan dengan latar belakang pendidikan yang lain ke pasar lulusan SMKTI.

Secara garis besar indikator masa depan lulusan SMKTI dipengaruhi persediaan (supply), dan jumlah permintaan (demand). Dengan demikian pengembangan atau untuk meningkatkan IFLM SMKTI tidak dapat dilihat dari satu sisi saja. Menurut Boediono (1997) pembangunan pendidikan jangan dipandang semata-mata sebagai suatu gejala persediaan (supply phenomena) dengan persoalan yang hanya terpusat pada bagaimana menghasilkan lulusan sebanyak-banyaknya dan bagaimana meningkatkan mutu pendidikan. Dalam kenyataannya pendidikan harus juga dipandang sebagai fenomena permintaan (demand phenomena) dengan persoalan utama pendidikan adalah untuk apa lulusan dihasilkan atau untuk apa mutu pendidikan ditingkatkan. Menurut Tilaar (1999) perencanaan pendidikan dan pelatihan yang dibutuhkan masyarakat masa depan adalah perencanaan yang didorong oleh mekanisme pasar (market driven) dan mendapat support dari masyarakat secara utuh. 


\section{Simpulan}

Keefektifan program pendidikan SMKTI dilihat dari angka partisipasi lulusan (APL) pada industri utama dan unit produksi dari industri utama tersebut, dan indikator pasar tenaga kerja yang akan datang bagi lulusan SMKTI, adalah:

1. APL bidang keahlian teknik mesin pada industri utama logam dan kerja mesin $>0,50$ (efektif), sedangkan pada industri lainnya $<0,50$ (tidak efektif).

2. APL bidang keahlian teknik elektro pada semua industri utama $<0,50$ (tidak efektif).

3. APL bidang keahlian teknik bangunan pada industri utama bangunan dan teknik sipil $>0,50$ (efektif), sedangkan pada industri lainnya $<0.50$ (tidak efektif).

4. APL setiap bidang keahlian di unit produksi, menunjukkan bahwa partisipasi bidang keahlian teknik mesin adalah 0,66 sampai 0,76 (efektif), partisipasi teknik bangunan 0,58 (efektif); dan partisipasi teknik elektro 0,36 sampai 0,43 (tidak efektif).

5. Indicator of future labour market (IFLM) program pendidikan SMKTI mempunyai kelayakan yang buruk, dengan indikator IFL $M=4,66>$ 1,15. Skor ini menunjukkan bahwa program pendidikan SMKTI tidak efektif.

\section{Daftar Pustaka}

Boediono (1997). Pendidikan dan perubahan sosial ekonomi. Yogyakarta: Aditya Media.

Camp, G. W., dan Hallison. (1984). Prosser's sixteen theorems, time for consideration. Omocron: Tau Theta.

Djojonegoro, W. (Nopember 1994). Kebijakan dan pengembangan pendidikan kejuruan di Indonesia. Makalah disampaikan dalam Seminar dan Temu Karya VII Forum Komunikasi FPTK Se-Indonesia, di FPTK IKIP Surabaya. 
Fung, K.M. (2001). An examination of the major components for a comprehensive manpower planning model. Hongkong: International Vocational Education and Training Association (IVETA). Diambil pada 4 Mei 2003, dari http:/ / www.ivetajamica.com.

Gallinelli, J. (1979). Vocational education, program at the secondary level: A review of development and purpose. Dalam Abramson, T; Tittle, C. K; dan Cohen L. London (Eds.), Handbook of vocational education evaluation (pp.19-36). London: Sage Publications.

Grip, A. de \& Heijke, H. (1998). Beyond manpower planning: ROA's labor market model and its forecastts to 2002. Research Centre for Education and the Labor Market, Faculty of Economics and Business Administration: Maastricht.

Hermanussen, J., et al (2000). Learning style in vocational work experience. Journal of vocational education research. Volume 25 (4).

Hough, J.R. (1993). Educational cost-benefit analysis - Educational Research. Loughborough University.

McMillan, J. H. \& Schumacher, S. (2001). Research in education: A conceptual introduction. New York: Addison Wesly Longman, Inc.

Miller, M. D. (1986). Principles and a philosophy for vocational education. Colombus-Ohio: The Nasional Center for Research for Vocational Education.

Pakpahan, J. (2002). Perkembangan pendidikan menengah kejuruan pada PELITA VI. Dalam Sunaryo, et al. Sejarah pendidikan teknik dan kejuruan di Indonesia, membangun manusia produktif. (pp. 221-272). Jakarta: Direktorat Pendidikan Menengah Kejuruan, Dirjen Pendidikan Dasar dan Menengah, Departemen Pendidikan Nasional.

Pasovac, E. J. \& Carrey, R. G. (1985). Program evaluation: Methods and case studies. New Jersey: Prentice-Hall, Inc. 
Shummer. R. (2001). A new, old vision of learning, working, and living: vocational eduacation in the $21^{\text {st }}$ century. Journal of vocational education research. Volume 26 (3).

Slamet, P.H. (2005). Hand out: Kapita selekta desentralisasi pendidikan di Indonesia. Jakarta: Departemen Pendidikan Nasional.

Tilaar, H.A.R. (1999). Kajian kritis mencari sistem pendidikan nasional. Makalah disajikan dalam Seminar Nasional Mencari Paradigma Baru Pendidikan Nasional Memasuki Milenium III, di Yogyakarta.

Willems. (1996). Manpower forecasting and modelling replacement demand: An overview. Maastricht: Research Cerntre for Education and Labour Market. Faculty of Economics and Business Administration Maastricht University.

Windham, D M. (1990). Improving the efficiency of educational systems: indicators of educational effectiveness and efficiency. New York: United States Agency for International Development, Bureau for Science and Technology, Office of Education. 